\title{
地方自治体の行政活動の総合的評価手法に関する研究
}

\section{A Study on the Comprehensive Evaluation Method of Administrative Activities in the Local Governments}

中島 卓也**青山 吉隆 ${ }^{* * *}$, 松中 亮治**** By Takuya NAKAJMA** ${ }^{* *}$, Yoshitaka AOYAMA ${ }^{* * *}$ and Ryoji MATSUNAKA ${ }^{* * * *}$

\section{1. 背景之目的}

近年、中央政府から、地方自治体一権限を委譲する地方 分権化が促進されており、また、住民一人一人の生活水準 が向上し、行政活動に対する関心が高まりつつある。さら に、財政状況が悪化している自治体は少なくない。このよ うな社会的背景のもと、自治体は、行政機構の効率化、住 民に対するアカウンタビリティの確保、行政立案能力、行 政遂行能力の向上が求められている。自治体は、これらに 対する有効な方法として行政評価に関心を寄せている。

そこで、本研究では、様々な行政評価手法の中でも、国 内外において、特に注目されている業績評価手法とベンチ マーク手法を用いた行政評価の特徵を整理し、それらの評 価手法の課題点のうち、特に、指標の総合化に着目し、指 標の総合化手法を提案する。そして、その提案した手法を 用いて、47都道府県を対象に自治体の行政活動の総合的 評価を試みる。

\section{2. 莱績評価手法とベンチマーク手法を用いた行政評価の 整理}

まず、はじめに、本研究における自治体の行政活動を図 ー1に示すような、政策-施策-事業の体系であると捉え、政 策-施策-事業の各活動を総称したものを行政活動と呼ぶこ ととする。

近年、業績評価手法とベンチマーク手法による行政評価 が注目されている。それは、他の行政評価手法と比較して 容易であり、経年比較や他の自治体との比較や目標までの 達成度の計測によって、自治体の課題分野の抽出が可能と なるためである。そして、住民の価值観の変化に対しても、 指標の変更のみで対応でき、業績評価手法とベンチマーク 手法による行政評価結果は、住民、自治体職員、首長等に とってわかりやすいためである。さらに、これらの手法は、 行政活動全般を網羅するように指標を選択することが可能 なため、自治体の行政活動の総合的評価手法として適当な ものであると考えられる。

キーワード:計画手法論、公共事業評価法

**学生員 京都大学大学院工学研究科

***フェロー 工博 京都大学大学院工学研究科

****正会員 工修 京都大学大学院工学研究科

于606-8501 京都市左京区吉田本町

Tel:075-753-5759 Fax:075-753-5759

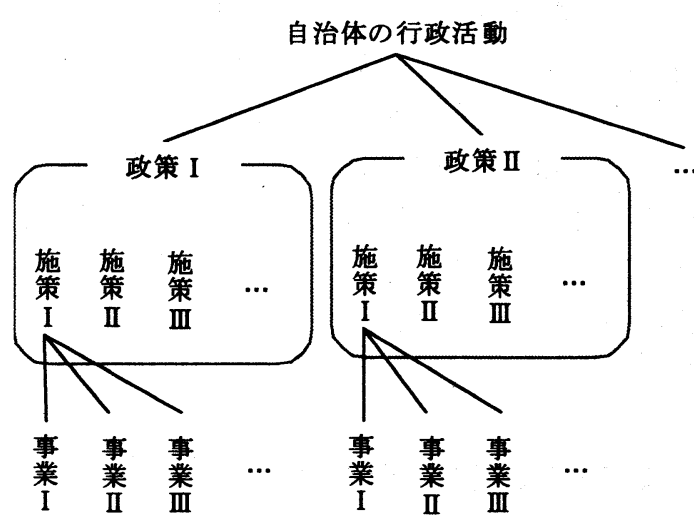

図-1 自治体の行政活動体系図

業績評価手法とベンチマーク手法は行政活動の企画立案 段階で設定した、長期、中期、短期的な目標の達成度、行 政活動が産出した効果、住民の満足度等の複数の指標を設 定し、これらを行政分野、自治体の行政活動方針と関連づ けをおこない体系的に分類し、これらを計測、分析するこ とで、現行の行政活動の課題点を抽出し、改善につなげる 手法である。

業績評価手法は、主に事業レベルを対象としたものであ り、アウトプット指標を用いていることが特徴である。ア ウトプット指標とは、例えば、老人介護サービスを受けた 延へ人数や道路整備延長距離の增加のように、行政が提供 したサービス量を現わす指標である。これらの指標は、行 政活動の結果を直接的に示す指標であり、他自治体の行政 活動や経済動向、社会的動向等からの影響が比較的少なく、 客観的な計測が可能である。そのため、効率性等の行政活 動の状態把握に適しているといえる。したがって、業績評 価手法は、自治体の行政活動の効率性を評価する手法とい える。ただし、各事業ごとに指標を設定するため、指標数 が多くなり、総合的な把握が困難なことが課題として挙げ られる。業績評価手法を用いた代表的な行政評価事例とし て、三重県で実施されている事務事業評価システムが挙げ られる。

ベンチマーク手法は、主に政策レベルを対象としたもの であり、アウトカム指標を用いていることが特徴である。 アウトカム指標とは、例えば、道路整備による移動時間短 縮量のように、行政活動の効果を表す指標である。したが って、人々が行政活動に対して抱いている評価に近く、べ ンチマーク手法は自治体の行政活動の有効性評価に適した 手法といえる。ただし、アウトカム指標は、社会経済活動 
の結果として顕在化する行政活動の効果を現わしたもので あり、他自治体の行政活動や経済動向、社会的動向等によ る影響を比較的受けやすい。そのため、自治体の行政活動 による効果の特定が困難なことが評価指標として用いる際 の課題である。ベンチマーク手法を用いた代表的な行政評 価事例としては、オレゴン州で実施されているオレゴンベ ンチマーキングが挙げられる。

これら両手法に共通する課題は、他自治体との比較や経 年的な比較から、課題を有する行政活動分野を抽出した後 に、次期への具体的な行政活動の提言が困難な点である。 また、指標を行政分野、行政活動方針と関連づけて分類を 行っているものの、指標值の中には、他自治体と比較して、 あるいは経年的に比較して、上回っているものや下回って いるものがあり、それら複数の指標を同時に考慮した自治 体全体の状態について総合的に評価することは非常に困難 である。

\section{3. 自治体の行政活動の総合的評価手法の提案}

前章で述べたように、業績評価手法とベンチマーク手法 における課題として、次期への具体的な行政活動に対する 提言や、自治体の行政活動全般の状態について総合的に評 価することが困難であった。その理由として、指標を個別 に比較していることが挙げられる。そこで、本章において は指標の総合化に着目し、指標の総合化による自治体の行 政活動の総合的評価手法の提案を行う。

従来、指標の総合化には、各指標の平均值を用いるケー スが多くみられる。しかし、人口構成、産業構成、地勢的 条件等の特徴は各自治体によって異なり、また、各自治体 が重視する行政分野も異なるため、各指標の平均値を用い る総合化方法は適当であるとはいい難い。そのため、各自 治体の行政分野の重要度を反映した指標の総合化を行う必 要がある。その方法として、行政分野の重要度を基に各指 標のウェイトを設定し、設定したウェイトと各指標の積和 する方法がある。しかし、各指標のウェイトをどのように 設定するかが課題となる。

この課題に対しては、住民に対するアンケート等から、 行政活動の重要度を計測し、それを各指標に対するウェイ トとして利用する方法がある。しかし、行政活動の重要度 は、各自治体で異なり、また同じ自治体でも、年次によっ て異なるため、各自治体が定期的に住民アンケートを実施 する必要があるため、このような方法は、時間的、費用的 な面から非常に困難である。

したがって、自治体全体の状態について総合的に把握し 評価するための望ましいウェイトの設定方法は、全自治体 に共通した絶対的なウェイトを設定するのではなく、各自 治体ごとに、それぞれの政策の重要度を反映させたウェイ トを簡便に設定することといえる。しかし、各自治体の行 政分野の重要度に関する情報の入手は困難なため、本研究 においては、各自治体の指標の総合化した值が最も高く評
価されるように各自治体ごとにウェイトを設定する。この ようなウェイト設定による指標の総合化は、各自治体の優 れた行政分野が評価され、従来の指標の総合化手法より各 自治体の特徵を反映させることが可能となると考える。

そこで、本章では、各自治体の指標の総合化した值が最 も高く評価される手法として、包絡分析法（Data EnvelopmentAnalysis：DEA）と、包絡分析法のコンセプ トを用いたウェイト最適化法について概説する。そして、 包絡分析法とウェイト最適化法を用い、全行政活動を対象 とし、課題を有する行政分野に対して定量的な改善案の提 示を可能とする自治体の行政活動の総合的評価手法を提案 する。

\section{（1）包絡分析法}

包絡分析法は、Charnes. A., W.W.Cooper, E.Rhodesに よって 1978 に構築された多入力多出力系の活動の相対的 効率性を計測する手法である ${ }^{3)}$ 。本節において、Charnes. A., W.W.Cooper, E.Rhodesによって構築された CCR モデル の効率性計測と改善案の算出方法を以下に示す。

\section{(a) CCR モデル ${ }^{3)}$}

今、 $\mathrm{m}$ 種類の入力指標と、 $\mathrm{s}$ 種類の出力指標を有する $\mathrm{n}$ 個の活動主体 DMU (Decision Making Unit) による活動 の集合に対して、対象とする $\mathrm{DMU}_{0}$ の活動の効率性は以下 の最大化問題を解くことにより求められる。

$$
\begin{array}{ll}
\text { 目的関数 } & \max \theta_{o}=\frac{u_{1 o} y_{1 o}+\cdots+u_{s o} y_{s o}}{v_{1 o} x_{1 o}+\cdots+v_{m o} x_{m o}} \\
\text { 制約式 } \quad & \frac{u_{1 o} y_{1 j}+\cdots+u_{s o} y_{s j}}{v_{1 o} x_{1 j}+\cdots+v_{m o} x_{m j}} \leq 1(j=1, \ldots, n) \\
& \left(x_{i j}, y_{r j}, v_{i o}, u_{r o} \geq 0\right)
\end{array}
$$

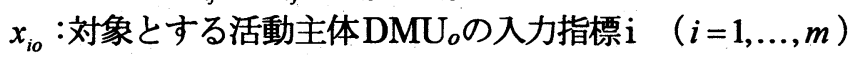

$x_{i j}: \mathrm{DMU}_{j}$ の入力指標 $\mathrm{i}(i=1, \ldots, m)$

$y_{r o}$ : 対象とする活動主体 $\mathrm{DMU}_{0}$ の出力指標 $\mathbf{r}$

$$
(r=1, \ldots, s)
$$

$y_{r j}: \mathrm{DMU}_{j}$ の出力指標 $\mathrm{r}(r=1, \ldots, s)$

$v_{i o}$ : 対象とする活動主体 $\mathrm{DMU}_{o}$ の相対的効率性を計測する

際の入力指標 $\mathrm{i}(i=1, \ldots, m)$ に用いる未知ウェイト

$u_{r o}$ : 対象とする活動主体 $\mathrm{DMU}_{0}$ の相対的効率性を計測する

際の出力指標 $\mathrm{r} （ r=1, \ldots, s)$ に用いる未知ウェイト

以上を線形計画に展開し、 $\theta$ の值が、最大となる最適ウ エイト $\left(v^{*}, u^{*}\right)$ を求める。この時の $\theta^{*}$ の值を $\mathrm{D}$ 効率值と 呼び、 $\theta^{*}=1$ となる $\mathrm{DMU}_{o}$ をD効率的であると呼び、 $\theta^{*}$ <1 となる $\mathrm{DMU}_{o}$ をD非効率的であると呼ぶ。また、 $\mathrm{DMU}_{0}$ がD非効率な場合、式 (2) の制約式の中に、 $\mathrm{DMU}_{0}$ に対 する最適ウェイトを用いた場合、等号が成立している $\mathrm{j} か ゙$ 必 ず1つ以上存在する。そのような $\mathrm{j}$ の集合を 
$E_{o}=\left\{j: \sum_{r=1}^{s} u_{r o}^{*} y_{r j}=\sum_{i=1}^{m} v_{i o}^{*} x_{i j}, j=1, \ldots, n\right\}$

とする。このとき、 $E_{o}$ に属する活動は $\mathrm{DMU}_{0}$ をD非効率と 判定させる基準となる活動である。そこで $E_{o}$ を $\mathrm{DMU}$ 。に対 する優位集合と呼ぶ。DMU。に対する優位集合は、DMU。 の活動を効率的な活動の改善する際に目標となる目標群で ある。

\section{(b) 生産可能集合 ${ }^{3)}$}

CCR モデルの改善案の算出には、入力指標と出力指標に よって構成される生産可能集合についての条件を定める必 要がある。そこで、本節では CCR モデルの生産可能集合に ついて、規模のリターンが一定、すなわち、入力值を $\mathrm{k}$ 倍 した際、 $\mathrm{k}$ 倍の出力值が得られると仮定した際の生産可能 集合に関する条件を述べる。

各DMU の活動を各DMU の活動を入力 $x \in \mathrm{R}^{\mathrm{m}}$ と出力 $\boldsymbol{y}$ $\in \mathrm{R}^{\mathrm{s}}$ の対と捉え、（x,y） で表すと各 DMU の活動は

$(\mathrm{m}+\mathrm{s})$ 次元のユークリッド空間の点として表すことがで きる。このときの DMU の集合を生産可能集合と呼び、記 号 $\mathrm{P}$ で表す。生産可能集合 $\mathrm{P}$ に対する条件を以下に示す。

\section{【条件 D 1]}

現在の各活動はP $\mathrm{P}$ 属する。

[条件 D 2]

$\mathrm{P}$ に属する任意の活動（x,y）に対して、それを $\mathrm{k}$ 倍 した活動（ $k x, k y ）$ は P 属する。

[条件 D 3]

$\mathrm{P}$ に属する任意の活動 $(\boldsymbol{x}, \boldsymbol{y})$ に対して、 $\overline{\boldsymbol{x}} \geq \boldsymbol{x} 、 \overline{\boldsymbol{y}} \leq \boldsymbol{y}$ を満たす $(\overline{\boldsymbol{x}}, \overline{\boldsymbol{y}})$ はPに属する。

[条件 D 4]

$\mathrm{P}$ に属する活動の非負結合の活動はP に属する。

入力データマトリクス $X=\left(\boldsymbol{x}_{i}\right)(i=1, \ldots, m)$ 、出力データ マトリクス $Y=\left(\boldsymbol{y}_{r}\right)(r=1, \ldots, s)$ を用いて、以上の仮定を満 たす集合 $\mathrm{P}$ は以下のように表される。

$P=\{(\boldsymbol{x}, \boldsymbol{y}) \mid \boldsymbol{x} \geq X \lambda, \boldsymbol{y} \leq Y \lambda, \lambda \geq \mathbf{0}\}$

$\boldsymbol{x}:$ 任意の活動の入カベクトル

$\boldsymbol{y}:$ 任意の活動の出力ベクトル

$X:$ 全DMUの入カマトリクス

$Y:$ 全DMUの出カマトリクス

$\lambda:$ 非負結合のパラメータ

\section{(c) CCR モデルの双対問題 ${ }^{3)}$}

CCR モデルは式 (1)、（2）の最大化問題を解くことに より効率性を求めるのではなく、以下に示す双対問題を解 くことの方が一般的である。それは、CCR モデルの双対問 題における制約式は、前述した生産可能集合を表しており、 D非効率となった DMU に対する改善案を算出することが できるためである。CCR モデルの双対問題における効率値
は以下の最小化問題を解くことにより求められる。

目的関数 $\min \theta_{o}$

制約式 $\theta_{o} \boldsymbol{x}_{o}-X \lambda \geq \mathbf{0}$

$$
\begin{aligned}
\boldsymbol{y}_{o}-Y \boldsymbol{\lambda} & \leq \mathbf{0} \\
\boldsymbol{\lambda} & \geq \mathbf{0}
\end{aligned}
$$

$x_{0}$ ：対象とする活動主体 $\mathrm{DMU}_{0}$ の入カベクトル

$\boldsymbol{y}_{o}$ ：対象とする活動主体 $\mathrm{DMU}_{0}$ の出カベクトル

$X:$ 全DMUの入力マトリクス

$Y:$ 全DMU の出カマトリクス

$\theta_{o}: \mathrm{DMU}_{o}$ の入カベクトルの縮小率

$\lambda:$ 双対変数

また、生産可能集合において定めた条件において、式 (4)、 （5）を満たす限り、DMU。の活動べクトルを他の活動べ

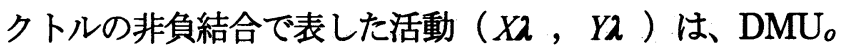
の活動 $\left(\theta_{o} \boldsymbol{x}_{o}, \boldsymbol{y}_{o}\right)$ より、優れている可能性がある。そこ で、入力の余剩 $s_{x} \in \mathrm{R}^{\mathrm{m}}$ と出力の不足 $s_{y} \in \mathrm{R}$ を产下のよう に定義する。

$\boldsymbol{s}_{x}=\theta_{o} \boldsymbol{x}_{o}-X \lambda$
$\boldsymbol{s}_{y}=Y \lambda-y_{0}$

式(6)、（7）は、式(3)、(4)、(5)の最適解 $\left(\theta_{o}^{*}, \lambda^{*}\right)$ に対して $\boldsymbol{s}_{x} \geq \mathbf{0} 、 \boldsymbol{s}_{y} \geq \mathbf{0}$ となる可能性がある。そこで、こ れらの入力の余剩量と出力の不足量は以下の最大化問題を 解くことにより求められる。

$$
\begin{aligned}
& \text { 目的関数 } \max \sigma=e_{x}+e s \text {, } \\
& \text { 制約式 } \boldsymbol{s}_{x}=\theta_{o}^{*} \boldsymbol{x}_{o}-X \lambda \\
& \boldsymbol{s}_{y}=Y \lambda-\boldsymbol{y}_{o} \\
& \lambda \geq \mathbf{0}, s_{x} \geq \mathbf{0}, s_{y} \geq 0
\end{aligned}
$$

e : 単位行列

$x_{b}: \mathrm{DMU}_{o}$ の入カベクトル

$\boldsymbol{y}_{o}: \mathrm{DMU}_{o}$ の出カベクトル

$X:$ 全DMUの入カマトリクス

$Y:$ 全DMU の出カマトリクス

$\boldsymbol{s}_{x}:$ 入力の余㮃ベクトル

$\boldsymbol{s}_{y}$ : 出力の不足ベクトル

$\theta_{o}^{*}:$ 式 (3)、(4)、（5）における最適解

$\lambda:$ 双対変数

式 (3)、（4)、（5）の最小化問題と式 (8)、（9)、（1 0) の最大化問題において、 $\theta^{*}=1$ となる $\mathrm{DMU}_{o}$ をD効率 的であると呼ぶ。また、 $\theta^{*}<1$ となる $\mathrm{DMU}_{o}$ を $\mathrm{D}$ 非効率で あると呼ぶ。また、 $\mathrm{DMU}_{o}$ がD非効率な場合、

$$
E_{o}=\left\{j \mid \lambda_{j}^{*}>0, j=1, \ldots, n\right\}
$$


を $\mathrm{DMU}$ 。に対する優位集合と呼ぶ。

また、DMU。の活動べクトルは、DMU。に対する優位集 合の活動べクトルの非負結合から表されている。 $\mathrm{DMU}$ のの 活動べクトルは $(\mathrm{m}+\mathrm{s})$ 次元空閒のベクトルであることか ら、 $\mathrm{DMU}_{o}$ に対する優位集合になり得る最大 $\mathrm{DMU}$ 数は $(\mathrm{m}+\mathrm{s})$ 個となる。

\section{(d) CCR モデルにおける改善案の算出方法3)}

活動 $\left(\theta_{o}^{*} \boldsymbol{x}_{\boldsymbol{o}}, \boldsymbol{y}_{\boldsymbol{o}}\right)$ は集合 $E_{o}$ を用いて以下のような式で 表すことができる。

$$
\begin{aligned}
\boldsymbol{\theta}_{o}^{*} \boldsymbol{x}_{o} & =\sum_{j \in E_{o}} \lambda_{j}^{*} x_{j}+\boldsymbol{s}_{x}^{*} \\
& =(\text { 優位集合の入力の非負結合 })+(\text { 余剩 }) \\
\boldsymbol{y}_{o} & =\sum_{j \in E_{o}} \lambda_{j}^{*} y_{j}-\boldsymbol{s}_{y}^{*} \\
& =\text { (優位集合の出力の非負結合) }- \text { (不足) }
\end{aligned}
$$

式（１１１）、（１１2）は以下のようになる。

$\sum_{j \in E_{o}} \lambda_{j}^{*} x_{j}=\theta_{o}^{*} x_{o}-s_{x}^{*}$

$\sum_{j \in E_{o}} \lambda_{j}^{*} y_{j}=\boldsymbol{y}_{o}+\boldsymbol{s}_{j}^{*}$

式（1 3)、（1 4) は、活動 $\left(\boldsymbol{x}_{o}, \boldsymbol{y}_{o}\right)$ の入力を $\theta_{o}^{*}$ 倍縮 小し、さらに、余剩を除去し、出力に不足分を追加すれば 効率的な活動になることを示している。

したがって、現在の DMU。が効率的な活動になるための 改善案は、 $\left(\theta_{0}^{*} x_{0}-s_{x}^{*}, y_{0}+s_{y}^{*}\right)$ である。ただし、これは 効率性改善のための一つの指針である点に留意する必要が ある。

以上までが、入力削減を目的とした改善案の算出方法で ある。この方法によって算出された改善案を入力指向の改 善案と呼ぶ。また、出力増加を目的とした改善案を出力指 向の改善案と呼び、出力指向の改善案も同様にして求める ことができる。

\section{（2）ウェイト最適化法}

本節においては、包絡分析法を応用したウェイト最適化 法の提案を行い、ウェイト最適化法を用いた指標の総合化 方法、改善案の算出方法について述べる。包絡分析法は、 各活動の入力指標、出力指標の両者を対象とし、効率性を 計測する手法であるが、ウェイト最適化法は、各活動の出 力指標を対象とし、指標の総合化を行う手法である。 (a) ウェイト最適化法の主問題

$\mathrm{s}$ 種類の出力指標で表される $\mathrm{n}$ 個の活動主体 DMU によ る活動の集合に対して、対象とする $\mathrm{DMU}_{0}$ の活動を表す指 標の総合化指標値は、以下の最大化問題を解くことにより 求められる。
目的関数 $\max \theta_{o}=u_{1 o} y_{1 o}+\cdots+u_{s o} y_{s o}$

制約式 $u_{1 o} y_{1 j}+\cdots+u_{s o} y_{s j} \leq 1 \quad(j=1, \ldots, n)$

$$
\left(y_{i j}, u_{r o} \geq 0\right)
$$

$y_{r o}$ : 対象とする活動主体 $\mathrm{DMU}_{0}$ の出力指標 $\mathrm{r}(r=1, \ldots, s)$

$y_{r j}: \mathrm{DMU}_{r}$ の出力指標 $\mathrm{r} \quad(r=1, \ldots, s)$

$u_{r o}$ ：対象とする活動主体 $\mathrm{DMU}_{o}$ の総合化指標值を計測す る際の出力項目 $\mathrm{r}(r=1, \ldots, s)$ に用いる未知ウェイト

この最大化問題の最適解 $\theta^{*}$ の值を総合化指標値と呼び、 $\theta^{*}=1$ となる $\mathrm{DMU}_{o}$ を最良な活動であると呼ぶ。また、 $\theta^{*}<1$ となる $\mathrm{DMU}_{o}$ を最良でない活動であると呼ぶ。また、 $\mathrm{DMU}_{o}$ が最良でない活動の場合、包絡分析法の場合と同様 に、式（1 6) の制約式の中に、DMU。に対する最適ウェ イトを用いた場合、等号が成立している $\mathrm{j}$ が必ず 1 つ以上存 在する。そのような $\mathrm{j}$ の集合を

$$
E_{o}=\left\{j: \sum_{r=1}^{s} u_{r o}^{*} y_{r j}=1, j=1, \ldots, n\right\}
$$

とする。このとき、 $E_{o}$ に属する活動は $\mathrm{DMU}_{o}$ を最良でない 活動と判定させる基準となる活動である。そこで $E_{o}$ を DMU。に対する優位集合と呼ぶ。DMU。対する優位集合 は、DMU。の活動を最良な活動に改善する際に目標となる 活動群である。

\section{(b) 活動可能集合}

ウェイト最適化法において改善案を得るためには、包絡 分析法の生産可能集合と同様な集合をウェイト最適化法に おいても定義する必要がある。本項では、包絡分析法の生 産可能集合々同等な、ウェイト最適化法における集合を活 動可能集合と呼ひ、活動可能集合の条件について述べる。

各 DMU の活動は出力 $\boldsymbol{y} \in \mathrm{R}^{\mathrm{s}}$ によって表現され、各 DMU の活動を $y$ で表すと各 DMU は s 次元のユークリッ ド空間の点として表すことができる。このとき DMU の集 合を活動可能集合と呼び、記号 P で表す。以下に、活動可 能集合 $P$ に対する条件を以下に示す。

[条件 W 1]

現在の各活動は $\mathrm{P}$ に属する。

[条件 W 2]

$\mathrm{P}$ に属する任意の活動 $\boldsymbol{y}$ に対して $\bar{y} \leq \boldsymbol{y}$ を満たす $\bar{y}$ は $\mathrm{P}$ に属する。

[条件 W 3]

$\mathrm{P}$ に属する活動の非負結合の活動は、P に属する。ま た、非負結合に用いられるパラメータの和は 1 以下であ る。

以上の条件を満たす集合 $\mathrm{P}$ は以下のように表される。 
$P=\{\boldsymbol{y} \mid \boldsymbol{y} \leq Y \lambda, \lambda \geq \mathbf{0}, \boldsymbol{e \lambda} \leq \mathbf{1}\}$

$e:$ 単位行列

$\boldsymbol{y}:$ 任意の活動の出力ベクトル

$Y:$ 全 DMU の出カマトリクス

$\lambda:$ 非負結合のパラメータ

ウェイト最適化法における活動可能集合と包絡分析法に おける生産可能集合との相違点は、“生産可能集合に属す る活動を $\mathrm{k}$ 倍した活動は生産可能集合に属する”という仮 定を行っていない点である。ウェイト最適化法において、 この仮定が成立する場合、活動可能集合に属する活動を $\mathrm{k}$ 倍した活動が、全て活動可能集合に属することとなるため、 活動可能集合の領域が有限でなくなる。そのため、改善案 の值が無限大となり、非現実的なものとなるためである。 そこで、ウェイト最適化法における活動可能集合において は、包絡分析法における生産可能集合の条件 D 3 およびD 4 に相当するものとして、新たに条件 W 3 を設定している。 この条件は包絡分析法における生産可能集合の条件 D 4 に

「非負合に用いられるパラメータの和は 1 以下である」と いう条件を加えたものとなっており、改善値は有限になる。 (c) ウェイト最適化法の双対問題

ウェイト最適化法においても、包絡分析法と同様な理由 により、双対問題を解くことで、総合化指標值の測定、改 善案の算出を行う。ウェイト最適化法の双対問題における 総合化指標值は以下の最小化問題を解くことにより求めら れる。

目的関数 $\min \frac{1}{\eta_{o}}=\lambda_{1}+\cdots+\lambda_{n}$

制約式 $\cdot \eta_{o} \boldsymbol{y}_{0}-Y \boldsymbol{\lambda} \leq \mathbf{0}$

$\boldsymbol{y}_{o}: \mathrm{DMU}_{o}$ の出カベクトル

$Y:$ 全DMU の出カマトリクス

$\eta_{o}: \mathrm{DMU}_{o}$ の出力ベクトルの拡大率

$\lambda:$ 双対変数

また、活動可能集合の仮定において、式（1８）を満た す限り、 $\mathrm{DMU}_{0}$ の活動ベクトルを他の活動ベクトルの非負 結合によって表した活動 $Y \lambda$ は活動 $\eta_{o} y_{0}$ より、優れている 可能性がある。そこで、出力の不足 $s_{y} \in \mathrm{R}^{\mathrm{s}}$ を以下のよう に定義する。

$\boldsymbol{s}_{\boldsymbol{y}}=Y \boldsymbol{\lambda}-\eta_{o} \boldsymbol{y}_{o}$

式（1 9）は、式（1 7)、（1 8) の最適解 $\left(\eta_{o}^{*}, \lambda^{*}\right)$ に対して $\boldsymbol{s}_{y} \geq \mathbf{0}$ となる可能性がある。そこで、これらの出 力の不足量は以下の最大化問題を解くことにより求められ る。

目的関数 $\max e \boldsymbol{s}_{y}$
制約式 $\boldsymbol{s}_{\boldsymbol{y}}=Y \boldsymbol{\lambda}-\eta_{o}^{*} \boldsymbol{y}_{o}$

$\boldsymbol{e}:$ 単位行列

$\boldsymbol{y}_{o}: \mathrm{DMU}_{o}$ の出カベクトル

$Y:$ 全 DMU の出カマトリクス

$\boldsymbol{s}_{y}$ : 出力の不足ベクトル

$\eta_{o}^{*}$ : 式 (1 7)、（1 8) の最適解における目的関数の值

$\lambda:$ 双対変数

式（1 7)、（1 8)）の最小化問題と式 (2 0)、(2 1) の最大化問題において、 $\theta^{*}=1$ となる $\mathrm{DMU}_{o}$ を最良な活動 であると呼び、 $\theta^{*}<1$ となる $\mathrm{DMU}_{0}$ を最良でない活動であ ると呼ぶ。また、 $\mathrm{DMU}_{o}$ が最良でない活動である場合、

$E_{o}=\left\{j \mid \lambda_{j}^{*}>0, j=1, \ldots, n\right\}$

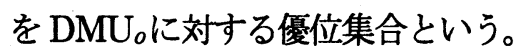

また、包絡分析法と同様に、ウェイト最適化法において も $\mathrm{DMU}_{o}$ の活動べクトルは、 $\mathrm{DMU}_{o}$ に対する優位集合の活 動べクトルの非負結合から表されている。 $\mathrm{DMU}_{0}$ の活動べ クトルは $\mathrm{s}$ 次元空間のベクトルであることから、 $\mathrm{DMU}_{0}$ に 対する優位集合になり得る最大 DMU 数は $\mathrm{s}$ 個となる。

（d）ウェイト最適化法における改善案の算出

活動 $\eta_{o}^{*} \boldsymbol{y}_{\boldsymbol{o}}$ は集合 $E_{o}$ を用いて以下のような式に表すこと ができる。

$\eta_{o}^{*} \boldsymbol{y}_{o}=\sum_{j \in E_{o}} \lambda_{j}^{*} y_{j}-\boldsymbol{s}_{y}^{*}$

式（2 2）は以下のようになる。

$$
\sum_{j \in E_{o}} \lambda_{j}^{*} y_{j}=\eta_{o}^{*} y_{o}+s_{y}^{*}
$$

式（2 3) は、活動 $\eta_{o}^{*} \boldsymbol{y}_{\boldsymbol{o}}$ は、現在の活動 $\boldsymbol{y}_{o}$ の出力を $\eta_{o}^{*}$ 倍拡大し、さらに、出力に不足分を追加すれば最良な活動 になることを示している。

したがって、現在の $\mathrm{DMU}_{\mathrm{o}}$ が最良な活動になるための改 善案は、 $\left(\eta_{o}^{*}-1\right) y_{0}+s_{y}^{*}$ である。ただし、これは最良な活動 になるための改善の一つの指針である点に留意する必要が ある。

以上まで DMU の総合指標值の計測方法を示してきたが、 実際に、総合化指標值の計測を行う場合、スラックレスな DMU と、同值の総合化指標值をとるスラックが生じてい る DMU が存在する可能性がある。これらは、総合化指標 值において同值であるため、同等な評価を得るが、実際、 これらの出力ベクトルを構成する指標值に差が存在するの で、これらの間には差が存在するといえる。そこで、式 ( 2 0 )、(2 1) で得られた出力の不足量の最適解を総合化指 標值に反映させた $\mathrm{t}$ 総合化指標值を示す。 


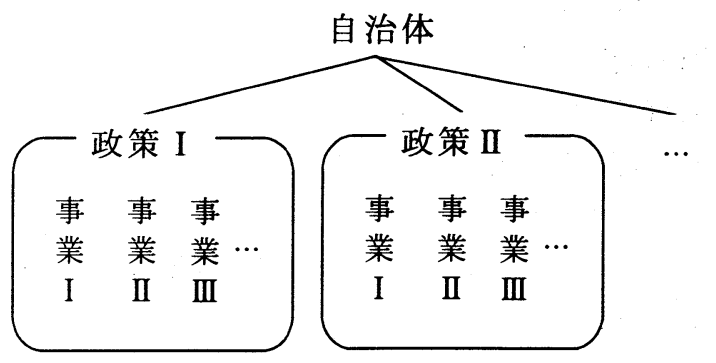

図-2 自治体の行政活動体系

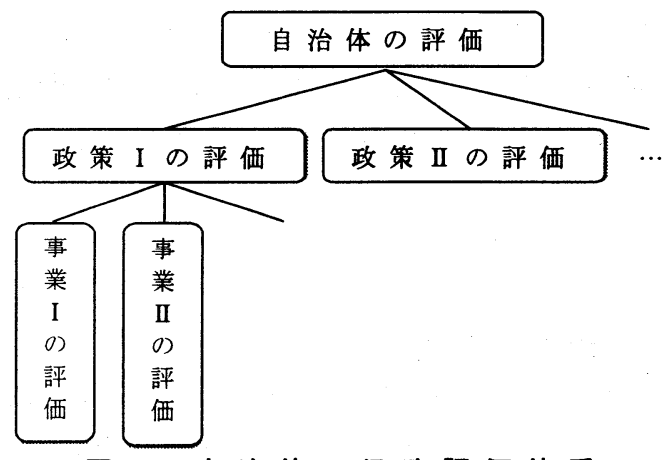

図-3 自治体の行政評価体系

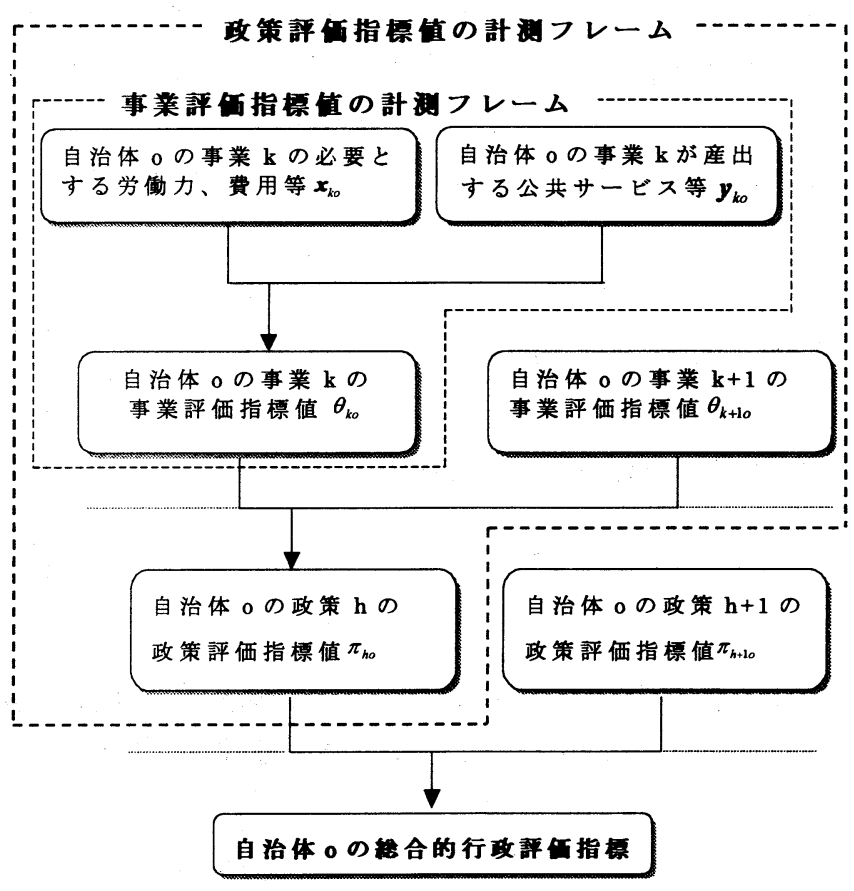

図-4 総合的行政評価指標值の計測過程の概略

$\tau_{o}^{*}=\frac{1}{\eta_{o}^{*}}\left(\frac{e y_{0}}{e y_{0}+e x_{y}^{*}}\right)$

\section{（3）自治体の行政活動の総合的評価手法}

本節では、包絡分析法とウェイト最適化法を用いた自治 体の行政活動の総合的評価手法について述べる。

自治体の行政活動を図一 2 に示すように、各政策は、各 政策と同様な目的を有する事業の集合と捉え、自治体の行 政活動全体は、政策の集合によって表されるものとする。 このとき、図ー3に示すように、政策の評価は、その政策
を構成する各事業の事業評価指標值を総合化したものと捉 え、自治体の評価は、政策に対する政策評価指標值を総合 化したものと捉える。なお、本手法の適用に際しては、各 政策、各事業は、他の政策、事業に影響を与えることなく、 互いに独立するように行政活動を体系化する必要があるが、 そのような体系化が困難な場合は、他の政策、事業からの 影響を現わす指標の導入が不可欠となる。本研究では、各 政策、事業は独立しているものと仮定して議論を進める。

自治体の行政活動の総合的評価は、まず、始めに、包絡 分析法を用いて各事業の入出力指標から効率值を計測し、 各事業の効率值を各事業に対する評価指標値として捉え、 これを各事業の事業評価指標值と呼ぶ。次に、ウェイト最 適化法を用いて、各事業の事業評価指標值を総合化し、そ の結果を政策に対する評価指標として拀え、これを政策評 価指標値と呼ぶ。そして、各政策の評価指標値に対して、 再びウェイト最適化法を用いて総合化し、その結果を自治 体の評価指標值として捉え、これを総合的行政評価指標値 と呼ぶ。自治体の総合的行政評価指標值の計測過程の概略 を図一 4 に示す。

\section{（4）自治体の行政活動の総合的評価における改善案 算出方法}

事業評価指標値と政策評価指標值の計測から、それぞれ 改善案が得られる。これらの改善案は、各事業がそれぞれ において効率的な評価を得るため、各政策がそれぞれにお いて最良な評価を得るための改善案である。一方、総合的 行政評価指標值の計測からも、各政策の政策評価指標値の 改善案が算出される。そして、算出された改善案の值が “1 未満”を示していることがある。これは、自治体の全政策 が最良な活動にならなくても、総合的行政評価指標値の計 測から得られた各政策の政策評価指標值の改善案を達成す ることで、総合的行政評価指標値は最良になることを示し ている。同様に、政策評価指標值の計測から得られた各事 業の事業評価指標に対する改善案を達成することで、ある 自治体の政策評価指標值は最良になることを示している。

そこで、本節では、政策評価指標値の改善案が “1未満” の值である政策に対して、その政策を構成する各事業の事 業評価指標値の改善案の算出し、ついで、その事業の評価 指標值の改善案が “ 1 未満” の值である事業に対して、そ の事業の事業評価指標値計測に用いた各指標に対する改善 案の算出する方法を述べる。なお、自治体の行政活動の総 合的評価手法における改善案算出方法の概略を図一 5 に示 す。

ここでは、まず総合的行政評価指標值の計測から、自治 体。における政策 $\mathrm{h}$ の政策評価指標值が $\pi_{h o}^{g}$ になることを示 す改善案が得られたとする。自治体 。 における政策 $\mathrm{h}$ の政 策評価指標值が $\pi_{h o}^{g}$ となるような各事業の事業評価指標値 の改善案は、政策 $\mathrm{h}$ を構成する他自治体の各事業の事業評 価指標値を、全て $\pi_{h o}^{g}$ 倍にすることで得られる。図一6につ いてみると、各事業の事業評価指標値を $\pi_{h o}^{g}$ 倍にすることは、 
包絡線が線分 $\mathrm{AC}$ から、線分 $\mathrm{A}^{\prime} \mathrm{C}$ ○移行することを表して おり、活動 $\mathrm{H}$ の目標は点 $\mathrm{H}^{\prime}$ から点 $\mathrm{H}^{\prime}$ となり、線分 $\mathrm{OH}$ "の 長さは、線分 $\mathrm{OH} の \pi_{h o}^{g}$ 倍になる。このときの改善案算出の 方法を以下に示す。

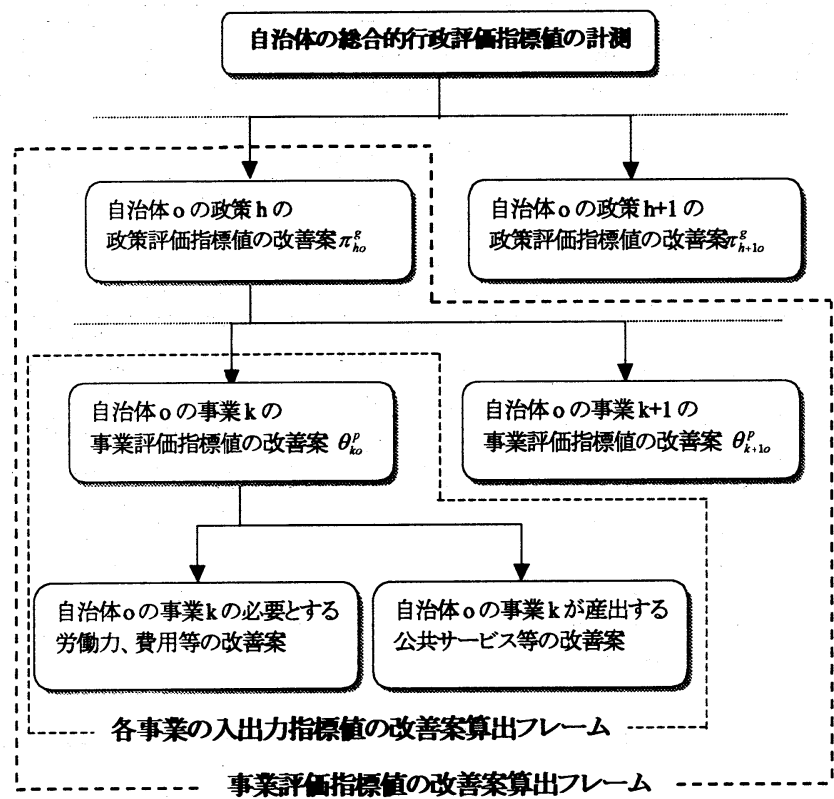

図-5 総合的評価手法における改善案算出方法の概略

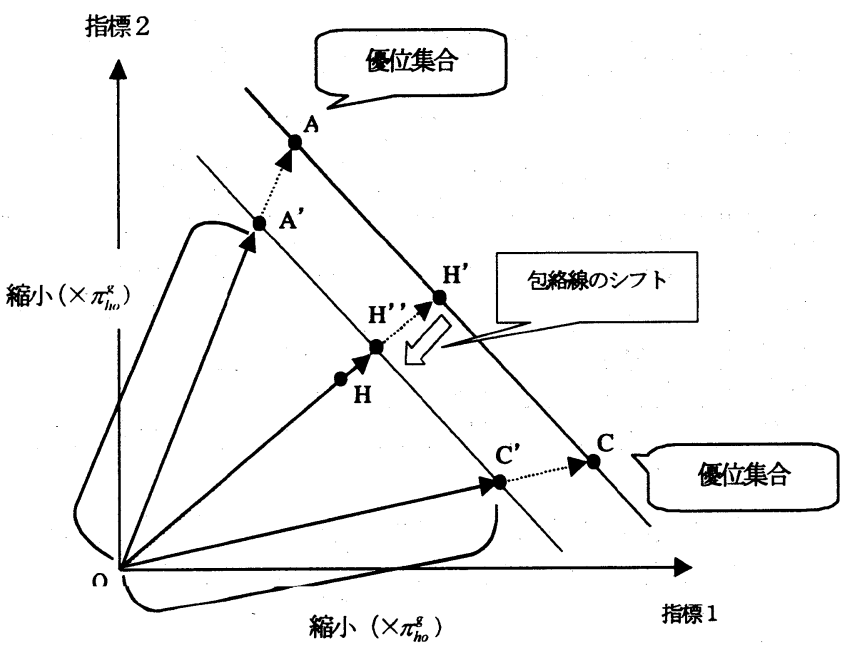

図-6 総合的評価手法における改善案の 算出方法のイメージ図

はじめに、全自治体の政策 $\mathrm{h}$ を構成する事業の事業評価 指標值を $\pi_{h o}^{g}$ 倍した際の、自治体 o における政策 $\mathrm{h}$ の政策 評価指標值を以下の最小化問題を解くことにより求められる。

目的関数 $\min \frac{1}{\pi_{h o}^{\prime}}=\lambda_{h 1}+\cdots+\lambda_{h n}$

制約式 $\pi_{h o}^{\prime} \boldsymbol{p}_{h o}-\frac{1}{\pi_{h o}^{g}} P_{h} \boldsymbol{\lambda}_{h} \leq \mathbf{0}$

$$
\boldsymbol{\lambda}_{h} \geq \mathbf{0}
$$

$\boldsymbol{p}_{h o}$ ：自治体。における政策 $\mathrm{h}$ （以下 $\mathrm{DMU}$ ho ）の活動状態べ
クトル

$P_{h}$ : 各自治体の政策 $\mathrm{h}$ を構成する事業評価指標マトリクス $\pi_{h o}^{\prime}: \mathrm{DMU} \mathrm{ho}_{\mathrm{o}}$ の政策評価指標值

$\pi_{h o}^{g}$ : 総合的行政評価指標值の計測から得られた自治体。 における政策 $\mathrm{h}$ の政策評価指標値の改善案

$\lambda_{h}:$ 双対変数

また、活動可能集合の条件において、式（2 5) を満た す限り、 $\mathrm{DMU}_{\mathrm{h}}$ の活動ベクトルを他の活動ベクトルの非負 結合によって表した活動 $P \lambda_{h} / \pi_{h o}^{g}$ は活動 $\pi_{h o}{ }_{h o} \boldsymbol{P}_{h o}$ より、優 れている可能性がある。そこで、出力の不足 $s_{y} \in \mathrm{R}^{\mathrm{s}}$ を以 下のように定義する。

$\boldsymbol{s}_{y}=\frac{1}{\pi_{h o}^{g}} P_{h} \lambda_{h}-\pi_{h o}^{\prime} \boldsymbol{p}_{h o}$

式 (2 7) は、式 (25)、(2 6) の最適解 $\left(\pi^{\prime *}{ }_{h o}, \lambda^{*}{ }_{h}\right)$ に対して $\boldsymbol{s}_{y} \geq \mathbf{0}$ となる可能性がある。そこで、これらの出 力の不足量は以下の最大化問題を解くことにより求められ る。

目的関数 $\max e_{y}$

$\boldsymbol{s}_{y}=\frac{1}{\pi_{h o}^{g}} P_{h} \lambda_{h}-\pi_{h o}^{*} \boldsymbol{p}_{h o}$

$\boldsymbol{e}:$ 単位行列

$\boldsymbol{s}_{y}:$ 出力の不足べクトル

$p_{h o}$ : 自治体oにおける政策 $\mathrm{h}$ （以下 $\mathrm{DMU}_{\mathrm{ho}}$ ）の活 動状態ベクトル

$P_{h}$ : 各自治体の政策 $\mathrm{h}$ を構成する事業の評価指標値

マトリクス

$\pi_{h o}^{\prime *}$ : 式 (2 5)、（2 6) における事業評価指標值

$\pi_{h o}^{g}$ : 総合的行政評価指標值の計測から得られた自治体。 における政策 $\mathrm{h}$ の評価指標値の改善案

$\lambda_{h}:$ 双対変数

最後に、政策 $\boldsymbol{p}_{\boldsymbol{h}}$ の改善案は、式（2 5)、（2 6) から得ら れた政策評価指標值の最適解 $\pi_{h o}^{\prime *}$ と式 (28)、(29) か ら得られた出力の不足の最適解 $\boldsymbol{s}_{y}^{*}$ を用いて $\boldsymbol{p}_{h o} / \boldsymbol{\pi}_{h o}^{* *}+\boldsymbol{s}_{y}^{*}$ となる。

以上までが、総合的行政評価指標値の計測から得た各政 策の政策評価指標値の改善案を反映した、事業評価指標値 の改善案の算出方法である。

事業評価指標值計測に用いた各指標の改善案の算出方法 についても、事業評価指標值の改善案算出方法と同様に求 めることができる。 


\section{4. 自治体の総合的行政評価指標值の計測}

本章では、3で提案した自治体の行政活動の総合的評価 手法を用い、ケーススタディとしてわが国の 47 都道府県 を対象に総合的行政評価指標値を計測する。本研究におい ては、自治体の行政活動は、図ー7で示すように、社会資 本整備政策、福祉政策、教育政策の 3 種の政策から構成さ れ、さらに、各政策は政策目標達成のために実施されてい る事業で構成されているとする。なお、各事業の事業評価 指標值計測に用いた指標とその出典を表一 1 に示す。

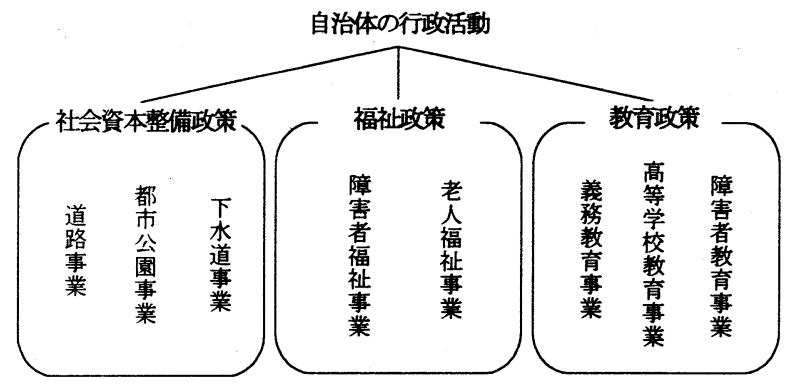

図-7 本ケーススタディにおける自治体の行政活動体系

\section{（1）道路事業の事業評価指摽值の計测}

ここでは、道路事業を、道路橋梁費と街路費を投入して、 実道路延長距離と舗装道路延長距離を増加させる事業とし て捉える。そこで、入力指標として、1995 年度の各都道府 県と各都道府県に属する市区町村の道路橋梁費と街路費の 合計值を用い、出力指標として 1995 年度の実道路延長距離 の増分と、舖装道路距離延長距離の増分を用い、道路事業 の事業評価 0 指標值を、包絡分析法を用いて、計測するこ ととした。道路事業の事業評価指標値と入出力指標の改善 割合の一部を表一 2 に示す。ここで、青森県を例にすると、 道路事業費を $57.2 \%$ 削減すること、あるいは、実道路延長 距離の増分を $179.4 \%$ 、舗装道路延長距離の増分を $133.6 \%$ 増加させることにより、青森県の道路事業は、優位集合と 同等の評価を得られることを意味する。

\section{（2）社会資本整備政策の政策評価指僄值の計测}

前節で得た道路事業の事業評価指標值と、道路事業と同 様にして得た、都市公園事業と下水道事業の事業評価指標 值をウェイト最適化法を用いて総合化し、それを各自治体 の社会資本整備政策の評価指標値とする。このときの、社 会資本整備政策の政策評価指標値の計測結果と各事業の事 業評価指標値の改善割合の一部を表一 3 に示す。

\section{（3）自治体の総合的行政評価指標值の計测}

前節で得た社会資本整備政策の政策評価指標值と、社会 資本整備政策と同様にして得た福祉政策と教育政策の政策 評価指標值をウェイト最適化法を用いて総合化し、それを 自治体の総合的行政評価指標值とする。総合的行政評価指 標值の計測において、不足を発生しているものの、その值 が “ 1 ”となる自治体が多くあった。そこで、総合的評価 指標值によって、最良か否かを判断するために、式（24)
表-1 各事業の事業評価指標値計測に用いた 指薥のデータの出典

\begin{tabular}{|c|c|c|c|c|}
\hline 政策 & 事業 & & 指標名 & 出典 \\
\hline \multirow{8}{*}{ 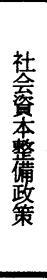 } & \multirow{3}{*}{ 道路事業 } & 入力指標 & 道路誘梁費 & 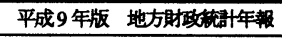 \\
\hline & & \multirow{2}{*}{ 出力指標 } & 実道路延長距雄 & 1999 年版 民力CD-ROM \\
\hline & & & 舗装道路延長距離 & 1999年版 民力CD-ROM \\
\hline & \multirow{2}{*}{\begin{tabular}{|c|} 
都市公園 \\
事業 \\
\end{tabular}} & 入力指標 & 都市公園費 & 平成9年版 地方財政影年報 \\
\hline & & 出力指標 & 都市公園面積 & 1999 年版 民力CD-ROM \\
\hline & \multirow{3}{*}{$\begin{array}{l}\text { 下水道 } \\
\text { 事業 }\end{array}$} & 入力指標 & 下水道費 & 平成9年版 地方財政知年年部 \\
\hline & & \multirow{2}{*}{ 出力指摽 } & 公共下水道利用世带数 & 1999 年版 民力CD-ROM \\
\hline & & & 雨水対策公共下水道整備率 & 1999 年版 民力CD-ROM \\
\hline \multirow{9}{*}{$\begin{array}{l}\text { 福 } \\
\text { 筱 } \\
\text { 策 }\end{array}$} & \multirow{4}{*}{$\begin{array}{c}\text { 障害者 } \\
\text { 福祉事業 }\end{array}$} & \multirow{3}{*}{ 入力指標 } & 身体障害者福裃施設数 & 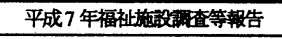 \\
\hline & & & 身体障害者福祉施設従事者数 & 平成 7 年福祉施配筒植等報告 \\
\hline & & & 身体障害者福祉費 & 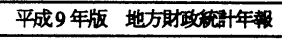 \\
\hline & & 出力指標 & 身体障害者福祉施設在所者数 & 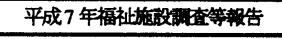 \\
\hline & \multirow{5}{*}{$\begin{array}{c}\text { 老人 } \\
\text { 福祉事業 }\end{array}$} & \multirow{3}{*}{ 入力指標 } & 老人福祉施設数 & 平成 7 年福祉施段洞查等報告 \\
\hline & & & 老人福祉従事者数 & 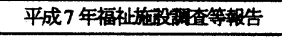 \\
\hline & & & 老人福祉費 & 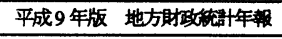 \\
\hline & & \multirow{2}{*}{ 出力指漂 } & 老人福祉施設在所者数 & 平成7 年福祉瓶取雨查等瞃告 \\
\hline & & & 老人デイサービス利用者数 & 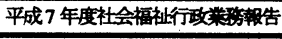 \\
\hline \multirow{13}{*}{$\begin{array}{l}\text { 謷 } \\
\text { 策 }\end{array}$} & \multirow{4}{*}{$\begin{array}{c}\text { 義務 } \\
\text { 教育事業 }\end{array}$} & \multirow{2}{*}{ 入力指標 } & 小中学校教員数 & 平成8 年度 学校基本喟查報告書 \\
\hline & & & 小中学校費 & 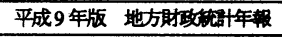 \\
\hline & & \multirow{2}{*}{ 出力指標 } & 長期欠席率 & 平成8 年度 学校基本相查垛告费 \\
\hline & & & 児童数+生徒数 & 平成8年度 学校基本研查墇告管 \\
\hline & & \multirow{2}{*}{ 入力指標 } & 高等学校教員数 & 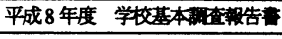 \\
\hline & & & 高等学校費 & 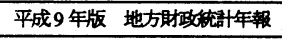 \\
\hline & & \multirow{2}{*}{ 出力指標 } & 大学進学摔 & 平成8 年度 学校基本䃒查報告書 \\
\hline & & & 生徒数 & 平成 8 年度 学校基本䃒查報告書 \\
\hline & & \multirow{3}{*}{ 入力指標 } & 障害者学校数 & 平成8 年度 学校基本調查報告書 \\
\hline & & & 障害者教育教員数 & 平成8 年度 学校基本㱚查報告書 \\
\hline & & & 特殊学釉費 & 平成9年版 地方財政知年報 \\
\hline & & \multirow{2}{*}{ 出力指標 } & 進学率+梳職率 & 平成8 年度 学校基本理查報告書 \\
\hline & & & 生徒数 & 平成 8 年度 学校基本析查埇告書 \\
\hline
\end{tabular}

表-2 各自治体の道路事業の事業評価指標値乙改善割合

\begin{tabular}{|c|c|c|c|c|c|}
\hline \multirow{2}{*}{ 自治体 } & \multirow{2}{*}{$\begin{array}{l}\text { 事業評価 } \\
\text { 指標値 }\end{array}$} & $\begin{array}{l}\text { 入力志向の } \\
\text { 改善割合(\%) }\end{array}$ & \multicolumn{2}{|c|}{$\begin{array}{c}\text { 出力志向の } \\
\text { 改善割合(\%) } \\
\end{array}$} & \multirow{2}{*}{ 優位集合 } \\
\hline & & 道路事業費 & $\begin{array}{l}\text { 実道路延長 } \\
\text { 距離の増加 }\end{array}$ & $\begin{array}{c}\text { 舗装道路延長 } \\
\text { 距離の増加 }\end{array}$ & \\
\hline 北海道 & 0.791 & 20.9 & 84.6 & 26.5 & 宮城 \\
\hline 青森 & 0.428 & 57.2 & 179.4 & 133.6 & 宮城 \\
\hline 岩手 & 0.707 & 29.3 & 413.7 & 41.4 & 宮城 \\
\hline 宮城 & 1.000 & 0.0 & 0.0 & 0.0 & 宮城 \\
\hline 秋用 & 0.636 & 36.4 & 57.2 & 74.2 & 宮娍 \\
\hline 山形 & 0.530 & 47.0 & 88.5 & 95.5 & 宮城 \\
\hline
\end{tabular}

表-3 各自治体の社会資本整備政策の政策評価指標値 -政策評価指標値と各事羓の事業評価指標値の改善割合-

\begin{tabular}{|c|c|c|c|c|c|}
\hline \multirow{2}{*}{ 自治体 } & \multirow{2}{*}{$\begin{array}{c}\text { 政策評価 } \\
\text { 指標値 }\end{array}$} & \multicolumn{3}{|c|}{ 改善割合（\%） } & \multirow{2}{*}{$\begin{array}{l}\text { 優位 } \\
\text { 集合 }\end{array}$} \\
\hline & & 道路事業 & 都市公園事業 & 下水道事業 & \\
\hline 北海道 & 1.000 & 0.0 & 0.0 & 0.0 & \\
\hline 青森 & 0.766 & 53.4 & 30.5 & 30.5 & 北海道、宫绮 \\
\hline 岩手 & 1.000 & 0.0 & 0.0 & 0.0 & \\
\hline 宮城 & 1.000 & 0.0 & 0.0 & 0.0 & \\
\hline 秋田 & 0.809 & 23.6 & 23.6 & 23.6 & 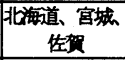 \\
\hline 山形 & 0.862 & 16.0 & 22.4 & 16.0 & 宮城 佐賀 \\
\hline
\end{tabular}

で示した不足量を考慮した $\mathrm{t}$ 総合化指標值を計測し、それ を $\mathrm{t}$ 総合的行政評価指標值とした。各自治体の $\mathrm{t}$ 総合的行 政評価指標值を表一 4 に示す。

（4）自治体の行政活動の総合的評価手法による各事業の 改善案算出

各事業の事業評価指標値計測において、事業評価指標値 
の計測に用いた入出力指標の改善案を算出したが、これら の改善案は、各事業の活動が、それぞれにおいて効率的な 活動になるための改善案であり、自治体の評価指標値が最 良となる改善量を考慮した改善案ではない。そこで、本節 では、自治体の総合的評価手法の改善案の算出方法を用い て総合的行政評価指標值が最良となるための、各事業の事 業評価指標值計測に用いた入出力指標の改善案の算出を行 う。表一 5 に、自治体の行政活動の総合的評価手法から得 られた道路事業における入出力指標の改善割合の一部を示 す。ここで、青森県を例にすると、道路事業費を $25.9 \%$ 削 減すること、あるいは、実道路延長距離の増分を $61.4 \%$ 、 舗装道路延長距離の増分を $34.9 \%$ 増加させることは、青森 県の総合的行政評価指標值が優位集合と同等の評価を得ら れるための、道路事業における必要条件を表している。た だし、入出力指標の改善割合は、入出力指標間の関係を考 慮していないため、直ちにその改善案を実行することは困 難な場合がある。しかし、具体的な数值として改善案が得 られるため、事業の効率性向上への指針として有効と思わ れる。また、自治体の行政活動の総合的評価手法から得ら れた各事業の改善割合の平均値の一部を表一 6 に示す。

\section{（5）本章のまとめ}

本ケーススタディにおいて、社会資本整備政策は、人口 が少ない都道府県の政策評価指標值が高くなり、人口が多 く、都市化の進んでいる都道府県の政策評価指標值が低く なる傾向となった。それは、人口が多く、都市化が進んで いる自治体は、一般的に社会資本整備が進んでおり、それ らの都道府県では、社会資本の改修費用や新規の社会資本 整備を行う際の用地取得の費用等が上昇することが一因と して考えられる。また、教育政策においては、人口が多く、 都市化の進んでいる都道府県の評価指標值が高くなる傾向
となった。教育政策を構成している各事業において、入力 指標として教員数を用い、出力指標として児童生徒数、ま たは児童数を用いたため、教員一人当たりの生徒数、また は児童生徒数が多くなると高い評価になる傾向がある。し たがって、人口が多い都道府県の教育政策の政策評価指標 は高くなる傾向にあると考えられる。以上のように、人口 が少ない都道府県が有利になる指標と、人口が多く、都市 化が進んでいる都道府県が有利になる指標が混在する中で、 本手法を用いることにより、総合的かつ定量的な都道府県 間の比較が可能となり、また、各都道府県の改善を必要と

\begin{tabular}{|c|c|c|c|c|c|}
\hline \multirow[t]{2}{*}{ 自治体 } & \multirow[t]{2}{*}{$\begin{array}{l}\text { 事業評価 } \\
\text { 指柏值 }\end{array}$} & \multirow[t]{2}{*}{$\begin{array}{c}\text { 事業評価指標值 } \\
\text { の改善案 }\end{array}$} & \multirow{2}{*}{$\begin{array}{r}\text { 入力志向の } \\
\text { 改善割合(\%) } \\
\text { 道路事業費 }\end{array}$} & \multicolumn{2}{|c|}{$\begin{array}{r}\text { 出力志向の } \\
\text { 改善割合(\%) }\end{array}$} \\
\hline & & & & $\begin{array}{l}\text { 実道路延長 } \\
\text { 跑離の増加 }\end{array}$ & $\begin{array}{c}\text { 舗装道路延長距 } \\
\text { 離の増加 }\end{array}$ \\
\hline 北海道 & 0.791 & 0.791 & 0.0 & 0.0 & 0.0 \\
\hline 青森 & 0.428 & 0.578 & 25.9 & 61.4 & 34.9 \\
\hline 岩手 & 0.707 & 0.707 & 0.0 & 0.0 & 0.0 \\
\hline 宮城 & 1.000 & 1.000 & 0.0 & 0.0 & 0.0 \\
\hline 秋田 & 0.636 & 0.724 & 12.2 & 13.8 & 26.2 \\
\hline 山形 & 0.530 & 0.595 & 10.8 & 12.1 & 16.3 \\
\hline
\end{tabular}

表-6 自治体の総合的行政評価指標値と 各政策の改善割合 （単位:\%)

\begin{tabular}{|c|c|c|c|c|c|c|}
\hline $\begin{array}{l}\text { 政 } \\
\text { 策 }\end{array}$ & 事業 & & 指標 & $\begin{array}{c}\text { 包絡法に } \\
\text { よる改善率 }\end{array}$ & \begin{tabular}{|l} 
総合的評価手 \\
法の改善率
\end{tabular} & $\begin{array}{l}\text { 改善率の } \\
\text { 縮小率 }\end{array}$ \\
\hline \multirow{8}{*}{$\begin{array}{l}\text { 社 } \\
\text { 会 } \\
\text { 資 } \\
\text { 本 } \\
\text { 整 } \\
\text { 政 } \\
\text { 策 }\end{array}$} & \multirow{3}{*}{$\begin{array}{l}\text { 道路 } \\
\text { 事業 }\end{array}$} & 入力 & 道路橋梁費 & 45.0 & 12.1 & 73.3 \\
\hline & & \multirow[t]{2}{*}{ 出力 } & 実道路延長距離の増分 & 210.4 & 33.0 & 84.3 \\
\hline & & & 舗装道路距離の増分 & 213.8 & 62.0 & 71.0 \\
\hline & \multirow{2}{*}{$\begin{array}{c}\text { 都市公園 } \\
\text { 事業 }\end{array}$} & 入力 & 都市公園費 & 65.8 & 18.1 & 72.5 \\
\hline & & 出力 & 都市公園面積の増分 & 629.2 & 91.4 & 85.5 \\
\hline & \multirow{3}{*}{$\begin{array}{l}\text { 下水道 } \\
\text { 事業 }\end{array}$} & 入力 & 下水道費 & 35.0 & 12.8 & 63.4 \\
\hline & & \multirow[t]{2}{*}{ 出力 } & $\begin{array}{c}\text { 下水道利用 } \\
\text { 世帯数の増分 }\end{array}$ & 106.5 & 35.6 & 66.6 \\
\hline & & & $\begin{array}{c}\text { 雨水対策公共下水道 } \\
\text { 整備率の増分 }\end{array}$ & 62.0 & 42.8 & 31.0 \\
\hline
\end{tabular}

表-4 各自治体の総合的行政評価指標値

\begin{tabular}{|c|c|c|c|c|c|c|c|c|}
\hline 自治体 & \begin{tabular}{|l}
$t$ \\
$t$ 総合的行政 \\
評価指標値
\end{tabular} & 優位集合 & 自治体 & \begin{tabular}{|c|}
$\mathrm{t}$ 総合的行政評 \\
価指標値
\end{tabular} & 優位集合 & 自治体 & \begin{tabular}{|c|} 
総合的行政 \\
評価指標値
\end{tabular} & 優位集合 \\
\hline 北海道 & 0.945 & 宮崎 & 福井 & 0.916 & 沖縄 & 山口 & 0.879 & 沖縄 \\
\hline 青森 & 0.871 & 福岡, 佐賀, 沖縄 & 山梨 & 0.813 & 佐賀 & 徳島 & 0.837 & 佐賀 \\
\hline 岩手 & 0.936 & 宮崎 & 長野 & 0.891 & 宮崎 & 香川 & 0.884 & 福岡, 佐賀 \\
\hline 宮城 & 0.942 & 宮崎 & 岐阜 & 0.805 & 佐賀 & 愛媛 & 0.931 & 佐賀 \\
\hline 秋田 & 0.883 & 福岡, 佐賀 & 静岡 & 0.830 & 佐賀 & 高知 & 0.748 & 沖縄 \\
\hline 山形 & 0.892 & 福岡, 佐賀, 沖縄 & 愛知 & 0.827 & 福岡, 沖縄 & 福岡 & 1.000 & \\
\hline 福島 & 0.892 & 佐賀 & 三重 & 0.974 & 宮崎 & 佐賀 & 1.000 & \\
\hline 茨城 & 0.905 & 佐賀 & 滋賀 & 0.856 & 佐賀 & 長崎 & 0.952 & 沖縄 \\
\hline 杤木 & 0.895 & 佐賀 & 京都 & 0.940 & 沖縄 & 熊本 & 0.897 & 福岡, 沖縄 \\
\hline 群馬 & 0.913 & 佐賀 & 大阪 & 0.783 & 佐賀 & 大分 & 0.865 & 沖縄 \\
\hline 埼玉 & 0.913 & 佐賀 & 兵庫 & 0.800 & 佐賀 & 宮崎 & 1.000 & \\
\hline 千葉 & 0.986 & 佐賀 & 奈良 & 0.944 & 佐賀 & 鹿児島 & 0.870 & 沖縄 \\
\hline 東京 & 0.736 & 佐賀 & 和歌山 & 0.820 & 福岡, 佐賀 & 沖縄 & 1.000 & \\
\hline 神奈川 & 0.819 & 福岡, 沖縄 & 鳥取 & 0.939 & 佐賀 & 平均値 & 0.891 & \\
\hline 新潟 & 0.825 & 福岡, 沖縄 & 島根 & 0.921 & 宮崎 & 標準偏差 & 0.067 & \\
\hline 富山 & 0.809 & 沖縄 & 岡山 & 0.921 & 福岡, 沖縄 & 最小値 & 0.736 & \\
\hline 石川 & 0.937 & 福岡, 沖縄 & 広島 & 0.880 & 福岡, 佐賀, 沖縄 & & & \\
\hline
\end{tabular}


する政策、事業を抽出し、それらに対する改善案の算出が 可能となった。さらに、福祉政策、教育政策の様な行政活 動分野に対して本手法を適用することは、各事業が産出す る公共サービスを貨幣価值換算する必要がなくなるため、 福祉、教育等の行政活動分野の定量的なパフォーマンスの 計測や比較が容易となる。そのため、本手法は、貨幣価值 換算が困難な公共サービスに対するパフォーマンス計測に 有効な手法といえる。

一方、本手法の課題として、各事業の事業評価指標値の 計測に用いる指標数をどの程度にするかという課題があが る。これは、比較対象とする自治体数と比較して指標数が 多い場合、ウェイトの組み合わせの自由度が大きいため、 評価指標值の平均值は上昇し、逆に、比較対象とする自治 体数と比較して指標数が少ない場合、ウェイトの組み合わ せの自由度が小さくなるため評価指標値の平均値は下降す る傾向がある。また、本手法から得られた改善案は、各自 治体が現状の行政活動方針を維持した際の改善案であり、 方針の転換を促す改善案を提示することは困難なことが挙 げられる。

\section{5. 本研究のまとめ}

本研究は、自治体の総合的行政評価手法として、業績評 価手法とベンチマーク手法の特徵を整理するとともに、指 標の総合化による自治体の行政活動の総合的評価手法を提 案した。そして、提案した手法を用いて 47 都道府県を対 象にケーススタディを行った。いままで、福祉、教育分野 の産出した公共サービスの計測は、サービス量を表す単位 が異なること等のため、福祉、教育分野を対象とした評価
が困難であった。そのため、自治体の行政活動全般を対象 とした行政評価が困難であった。そこで、本研究で提案し た自治体の総合的行政評価手法は、福祉、教育分野が産出 した公共サービスを定量的な計測を可能とし、さらに、自 治体の総合的行政評価を可能とする成果を得た。

本研究の課題として、自治体の行政活動の総合的評価手 法は、包絡分析法とウェイト最適化法を用い、構築したも のである。包絡分析法とウェイト最適化法は、効率的、あ るいは最良と評価されない活動に対する改善案を算出した が、これらの改善案は、現在の活動方針を維持した上での 改善案であって、方針の転換を促すものではない。したが って、行政全般を対象とした評価手法における改善案も同 様に、現在の行政活動方針を維持した上での改善案であり、 行政活動方針の転換を示すものではないことが挙げられる。 また、総合的行政評価値を計測する際に、評価対象とする 自治体に対して最も好意的に設定した各指標のウェイトは、 自治体の行政分野の重要度を反映したウェイトと異なる可 能性がある。

最後に、今後の方針として、計測した総合的行政評価指 標值と、人口増加率等の社会的同行を表す指標や、県内総 生産等の経済的同行を表す指標との関係を検証し、評価指 標值計測に用いた指標の妥当性や評価指標值の計測結果の 検証を行うことが考えられる。

\section{【参考文献】}

1）東京都政策報道室, 米英の地方行政における政策評価の新しい 潮流, 1999

2) 政策評価研究会, 政策評価の現状と課題、木鏍社, 1999

3） 刀根薰, 経営効率性の測定と改善一包絡分析法 DEA による一, 日科技連, 1993

地方自治体の行政活動の総合的評価手法に関する研究

各自治体では、行政機構の効率化や、住民からの信頼の獲得、行政立案能力と行政遂行能力の向上を促す有効 な方法として、行政評価に関心を寄せつつあり、様々な行政評価手法の中でも、自治体の行政活動に関する指標 を分野別に分類した業績評価手法やベンチマーク手法が注目されている。しかし、これらの手法には、複数の指 標を同時に把握するための指標の総合化に課題があるといえる。そこで、本研究では、包絡分析法と包絡分析法 を応用したウェイト最適化法を用いた指標の総合化手法を提案し、全国 47 都道府県を対象に提案した総合化手 法の適用を試みる。

A Study on The Comprehensive Evaluation Method of Administrative Activities in the Local Governments Takuya NAKAJIMA, Yoshitaka AOYAMA and Ryoji MATSUNAKA

Each Local Government needs increasing the efficiency of the Administrative System, getting the confidence for the citizens and improving the ability of planning and performing. So it is interested in the Evaluation of Administration Activities. Today, The Results Evaluation Method and The Benchmark Method become one of the effective evaluation methods. However, they have the problem how to comprehend their indicators. So in the study, we suggest the method of the Comprehending their indicators using the Data Envelopment Analysis and the Weight Optimum method. And we apply this method to the Comprehensive Evaluation of Administrative Activities in the local governments. 